\title{
Analysis of Spacial Narrative in Point Omega
}

\author{
Yue $\mathrm{Hu}^{1}$ \\ ${ }^{1}$ Foreign Language College, Jiangxi Normal University, Jiangxi, China \\ Correspondence: Yue Hu, Foreign Language College, Jiangxi Normal University, Jiangxi, China. E-mail: \\ 820539376@qq.com
}

\author{
Received: January 5, 2020 Accepted: February 10, 2020 Online Published: February 21, 2020 \\ doi:10.5539/ells.v10n1p62 URL: https://doi.org/10.5539/ells.v10n1p62
}

\begin{abstract}
Spatial narrative is an emerging theory of Narratology since Joseph Frank proposed it in 1945. Point Omega is one of Don Delillo's work, completed in 2010, mainly tells stories about two persons: a nameless person alone in museum exhibition hall to watch a silent film and a high-level war adviser Richard Elster, away from the city in seclusion in the desert. This paper use spatial narrative to analyze the theme of Point Omega, which is divided into four parts: the first part briefly introduces spatial narrative and Point Omega; in the second part, the literature in China and others of spatial narrative and Omega Point are reviewed; in the third part, the text is interpreted from three aspects of spatial narrative, physical form, text structure and narrative perspective; the fourth part summarizes how the novel reflects the influence of the concept of time on people's lives.
\end{abstract}

Keywords: Don Delillo; Point Omega; Spatial narrative

\section{Introduction}

\subsection{Spatial Narrative}

Spatial narration is a theory emerging in the last century, first put forward by Joseph Frank (1945) in his article Spatial Forms in Modern Literature. Since then, many scholars have put forward relevant theories, and space theory is developing and improving continuously. Using spatial narrative theory can not only analyze literary texts, but also apply to images, architecture and other artistic aspects. Up to now, spatial narrative is not only applied in literary works, but also used to analyze images, films and art works, which is a comprehensive development. Although the study of spatial narrative started late in China, and it was not used to analyze literary works for the first time, it did not prevent this theory from shining brilliantly in the literary circle.

\subsection{Don Delillo and Point Omega}

Don Delillo was born in 1936 in Fordham, an Italian-American neighborhood in the Bronx, New York. He has published many works, his first novel Americana was published in 1971. The publication in 1985 of White Noise brought him widespread recognition. It was followed in 1988 by Libra, a bestseller. DeLillo has twice been a Pulitzer Prize for Fiction finalist (for Mao II in 1992 and for Underworld in 1998). Other works are Great Jones Street, Ratner's Star, Players, Running Dog, The Names, The Body Artist, Cosmopolis, Falling Man.

Point Omega is a novel by Don Delillo in 2010. It involved two films-Hitchcock's Psycho, a thriller movie, and Douglas Gordon's 24 Hour Psycho, which was extended to 24 hours and installed at the Museum of Modern Art in New York in the summer of 2006. Don Delillo was inspired to write Point Omega. The story of the nameless man alone in a museum gallery watching a two-frame-per-second silent film and of the government's top war adviser, Richard Elster, retreating from the city into the desert, reflects on time and self, as well as reality beyond surface. These two stories are aimed to think about time and people themselves, and the true reality.

The background of the creation of Point Omega is that after the September 11 attacks and the Iraq war, people affected by the war have changed their views on life and time. In the novel, when the nameless man watches the movie, his mind constantly jumps between the movie and the reality, his observation becomes detailed, and he feels that time has become slow. When Elster stays in the desert, time seems to stand still in the face of the vast expanse of desert and ruins. With the vast space in the novel, the view of time here also becomes slow.

\section{Research on Spatial Narrative}

The concept of "spatial narrative" was first proposed by Joseph Frank, professor of Comparative Literature at Princeton University, who published the theory of novel spatial form put forward by Spatial Form in Modern 
Literature in 1945. Among his paper, he proposed two crucial concepts- "juxtaposition" and "crossreference". Juxtaposition refers to the juxtaposition of images, symbols and connections implied in a text so that they can better integrate the text and form a whole. Crossreference is a combination of text and non-text so that readers can better understand the text. He analyzes the spatial form of modern novels from three aspects of narrative, namely, the spatial form of language, the physical space of stories and the psychological space of readers. After that, more and more scholars devote themselves to the study of spatial narration. Seymour Chatman's Story and Discourse: Narrative Structure in Fiction and Film (1978) distinguishes between "story space" and "discourse space", the latter refers more to the creation environment of the narrator than the former.W.J.T. Mitchell (1980, 539-567). In his paper Spatial Form in Literature: Toward a General Theory, he classifies four types of literary space: the literal layer, the descriptive layer, the sequential principle of textual expression, and the metaphysical space after the story. Gabriel Zoran $(1984,309-335)$ in his article Towards a Theory of Space in Narrative, proposed the space of the narrative as a whole, creatively put forward the narrative space representation of three levels: topographic space (static entity space), the space and time body space (by the event and the motion form of space structure, also can be as simple as the "time", it includes both synchronic and diachronic relations), the space of the text (text of space). In the Space in Fiction, Ruth Ronen (1986, 421-438) proposed the concept of "Frame", which represents the structure of space. This is similar to geological space, but it refers to the space constructed in the text in which the things described happen, either real or imaginary.

It is not in the field of literature when Chinese scholars begin to study spatial narrative. In 1996, Shuangxi Yin mentioned the narrative significance of city as a kind of space in fine arts when discussing urban engraving, and mentioned "spatial narration" for the first time. In 1999, Shijun Zhang used spatial narrative to study the spatial nature of the narrative concepts in the Dream of Red Mansions and other Ming's and Qing's novels. The space narrative gradually permeated into the field of literature research. After that, Diyong Long's doctoral thesis (2008) first proposed the goal of constructing a subject of spatial narrate, and specifically discussed the spatial form, spatial energy and image narrative research in modern novels. His paper discusses the "spatial turn", the spatial dimension of narrative, and the contrast between image narrative and text narrative. So far, there are more than 800 verified articles about spatial narration on the China National Knowledge Infrastructure. Most Chinese spatial narrative theories are used to analyze novels, as well as art works and films. In addition to numerous articles analyzing novels, films, architecture and art with spatial narration, there are also several articles summarizing the development process of spatial narration by Chinese scholars. Haiyan Cui's Domestic Space Narrative Research and Its Reflection (2009, 42-47), Miaomiao Ning and Wanmin Zhang's Domestic Space Narrative Research Review (2013, 124-127), Wei Sun's master's thesis Review and Comment on the Domestic Spatial Narrative Research (2018), these three papers are the current comments on Chinese space narrative research. Haiyan Cui's thesis studies six aspects of spatial narrative: the spatial turn of narrate research; Literature, film and television text space narrative analysis; The rise and development of space narrative theory; Space narrative research field; Sorting out the concept of space narration in ancient China; Discussion on the theory of image narration. The paper of Miaomiao Ning and Wanmin Zhang summarizes the process and results of domestic research on spatial narration up to 2012, and displays the number and trend of spatial narration papers published during this period in the form of bar graph. Wei Sun's paper discussed the present domestic space narrative research on three areas, namely the philosophy of the space narrative research (space and time, psychological, social relations), the content of the space narrative research (space and scene, character, image association), the space in the form of narrative research (the physical form, text structure, narrative Angle of view of space), finally a brief evaluation of the space narrative of the achievements and shortcomings.

\section{Analysis of Special Narrative in Point Omega}

\subsection{Physical Form}

The novel Point Omega involves three physical spaces-the museum of Modern Art in New York where 24 Hour Psycho is shown, the hotel in the movie and the desert away from city. In the gallery, is narrow and completely black, the only light comes from the film on the screen. An nameless man stands against the north wall, watching the movie. The desert, by contrast, is empty and bright. This corresponds to the theme of the old man in the article, Richard Elster. He was invited by "me", Jim Finley, to share his views on the war. Although he supported war and participated in the planning of the war, he also believed that war created a closed world (Delillo, 2010). He moved from the city to the desert as a "spiritual retreat", where he can enjoy life freely and at ease. With the arrival of Jessie, Elster's daughter, his world slowly converged on whatever he wanted, and he wanted to be there for her all the time. As he saw it, Jessie "is his closed space." He felt the warmth of family from the war. And at the last moment, Jessie's disappearance also meant that his world from the "closed" opened. Before his daughter's accident, he still believed in the justice of war. Later, he was immersed in the grief of the 
loss of his daughter, only to realize the brutality of the war. Reality, however, forced him to return to the city to work as a war adviser.

For Finley, he thought of the city's tiny apartments, the countless bills and chores, like a cage holding people in and pushing them forward. Desert space was free and broad, whether it was the sun or wind and rain, could make people feel the reality of nature.

The physical space of the story can be used to represent time and promote the development of the story Diyong Long (2014) once said. The film in the museum, which stretched out to 24 hours, slowed the viewer down so much that the nameless man could count the rings in the shower curtain. In the transition between film and reality, he watched the development of the plot while observing the people around him and thinking about the relationship between things.

Richard Elster and Finley thought that even time slowed down when they were in the desert and they were enjoying life. He could sit all day, watching the scenery in silence, listening to the wind blowing over the mountains, slowly and freely. This life was brought back to reality after Jessie disappeared suddenly, and time sped up as they searched for her for days without success. Slow and fast are here in full swing.

24 Hour Psycho is set in a fictional cinematic time and space, a black-and-white screen world. The unnamed man watched the film in the cold, dark, cramped, enclosed art galleries of New York's museum of modern art. Both the screen world and the art exhibition hall belong to the inner world of the museum of modern art, symbolizing a kind of fictional art world. Finley and Elster are in a California desert, a vast, empty, bright, hot space that is both a natural space and an external world and a symbol of the real world. In essence, therefore, the competition between these three stories is also the competition between film and fiction, fiction and reality, or rather, the competition between art and life.

\subsection{Textual Form}

In Diyong Long's Spatial Narratology (2008, 91-98), it is proposed that there are several spatial forms of narrative structure: 1) Chinese boxes, which are similar to "Russian dolls" in that narrative stories are set one after another, rather than simply juxtaposed; 2) the circle structure, the development of the plot is a link between the preceding and the following, and it continues to the beginning of the novel, forming a circle; 3) chain structure, based on Calvino's "time zero" theory, the stories are link to each other, so more and more rings, from one two three to dozens, which forms a chain structure; 4) other types, orange petals, spelling scheme, dictionary body, etc. Wei Sun (2018) also talked about spatial classification in his master's thesis Review and Comment on the Domestic Spatial Narrative Research. In addition to the four types mentioned above, there are also juxtaposing forms and sub-forms.

The three physical spaces of the Point Omega, mainly in the form of circles, have corresponding chapters. The description in museum is the first chapter and the sixth chapter, named Anonymity and Anonymity 2, which describe the film space at the same time, covering two physical spaces; The desert part is described in the middle four chapters, entitled simply $1,2,3,4$. At the first of this novel, it describes an nameless man watching a movie in a museum, his mind drifting as the camera changes. Then, the three protagonists of the novel, appeared in turn, "I", i.e. Finley, was finding a secluded defense expert Richard Elster who lived in dessert, hoping he can join "my" movie about war. Elster's daughter Jessie also come in a few days later, but when "I" and Elster were about to leave for New York, Jessie was missing; no one knew where she was. Finally, the police found a knife with blood on it; most of them thought Jessie had been murdered. Helplessly, "I" and Elster returned to the city on business. That's the end of desert, the last chapter is back to the museum, this nameless man was still watching the movie, but he's been watching it for six days. That day a strange woman came and talked to him, not only about the murder in the movie, but also about life and philosophy, which seemed casual and real in daily life. Whether in the movie, in the museum or the desert, the shadow of death and grief hangs over on it.

24 Hour Psycho is a thread that runs through the novel. The novel begins and ends with the nameless man watching the film, and Finley and Elster meet because they saw it together at the museum.

From the perspective of the narrative structure of the novel, the first and last parts show a fictional art, while the middle part shows a real life. Through this arrangement, Delillo seems to suggest that real life is surrounded by art, which begins and ends with art. It is precisely this arrangement of embedded structure that makes the novel have paradoxical effect, implying a series of binary opposition. From the perspective of space, the museum of modern art and the desert constitute the two Spaces of the novel, and there are binary opposition relations between them, such as civilization and nature, dark and light, narrow and broad, internal world and external world, film and novel, fiction and reality, and so on. Different space switches each other, set off each other, 
achieve unity in mutual competition.

\subsection{In the Form of Narrative Perspective}

First of all, the differences between narrative perspective and voice should be distinguished. In Narrative Discourse (1990), Gerald Genette argued that the perspective is to study who sees, that is, who is observing the story; Sound is the study of who speaks it, the language that the narrator conveys to the reader. That is to say, the perspective is for the character, while the voice is for the narrator. The narrator only reports and explains what the character sees and thinks, and the perspective and sound are in a separate state. N. Friedman, in his book Point of View in Fiction: The Development of a Critical Concept, divides perspectives into eight categories: 1) editorial omniscience; 2) neutral omniscience; 3) statement of the first witness; 4) narration of the first-person protagonist; 5) multiple selective omniscience; 6) selective omniscience; 7) dramatic style; 8) camera mode. Genette simplified these and proposed the "three-point method" of perspective: 1) "zero focus" or "no focus" (narrator > characters); 2) "inner focus" (narrator = character); 3) "external focus" (narrator $<$ character). Dan Shen's book Narrative Studies and Stylistics of Novels (2004) summarized previous experience and proposed four types of perspectives: 1) zero perspective, that is, the traditional omniscient perspective; 2) internal perspective, including not only the third-person "fixed limited perspective", but also the narrative perspective of the first-person protagonist and the narrative perspective of the first-person witness, that is, "my" eyes when recalling the previous events; 3 ) the external perspective of the first person, that is, the present perspective of "I" recalling the past; 4) third person external perspective, i.e. Genette's "external focus".

According to Dan Shen's perspective theory, the two main physical scenes in Point Omega are all from the internal perspective. The difference is that the museum chapter uses the third person, while the desert chapter uses the first-person narrative perspective.

The third person inner perspective is focused, not comprehensive. This novel only describes what anonymous saw and thought when he watched the movie, but does not depict the inner world of other characters (such as the woman he talked with), that is, the words, deeds, appearances and backgrounds of the characters are transmitted to readers through the nameless man's mind, and there is no summary evaluation. Because the reader has a limited knowledge of other people, and all other information comes from this man, what he thinks is a good indicator of his personality traits - patience, careful observation, and not good at communication. First, the male moviegoer at constantly reflects, chewed and evaluated the content of the film as he watched it. He forced his way into the story world of the movie as a reviewer, separated the characters and their actors from the real world experience and vision, and changed the logical way of the movie 24 Hour Psycho movement. Second, slow played the movie Psycho in twenty-four hours, had firmly attracted the attention of the nameless man. He interrupted his personal thinking and comments by other viewers, even the door security also disturb his thoughts from time to time.

In the fourth chapters of the desert, Richard Elster and Jessie are described in the first person, by Jim Finley. This narrative perspective is conducive to bringing readers into the story and can directly and subjectively stimulate sympathy and create suspense (Shen, 2004). For example, the chapter in which Jessie is missing does not directly describe her whereabouts. It only describes how "I" and Elster began to search for Jessie after finding her missing all night, asking the police for help, and how Elster's life turned into a mess after he lost his daughter. After this incident, Elster also understood the pain of losing family and the disaster caused by war to others.

\section{Discussion}

The three spaces in Point Omega (the hotel on the film, the museum, the desert) seem unrelated, but they intersect. Whether it's the bloody case in the movie or the disappearance of Jessie in the desert, their themes revolve around "conflict". Broad and narrow, fast and slow, reality and ideal, and so on, these are inevitable conflicts.There are two main themes in this novel: the disaster of war and the influence of fast speed development to daily life. For the former theme is under the shadow of 911 and Iraq War. The impact of the war affected almost every ordinary person's daily life, leading to depression, fear, even loss of a loved one, or a sense of guilt and remorse. For the later theme, it seems that everything in modern life is passing quickly, information is fast, communication is fast. 24 Hour Psycho does the opposite, deliberately lengthening its timeline to allow viewers to think about life at a slower pace. Watching a film not only allows concentration, it depends on it. The less you say, the more you focus, the more you see. We can only find our own life in this fast-paced and stressful age without resting on our feet.

\section{Acknowledgments}

I would like to thank my parents, teachers and friends who accompany me, and thank them for their helpful 
suggestions. Only with their support, encouragement and help can I better complete the paper. I would also like to thank the books, monographs and papers of scholars cited in this paper. Without the inspiration and help of their research results, I would not have been able to complete the final writing of this paper. Due to my limited academic level, the paper inevitably has shortcomings. I sincerely hope that you can criticize and correct it!

\section{References}

Chatman, S. (1978). Story and Discourse: Narrative Structure in Fiction and Film. Ithaca: Cornell University Press.

Cui, H. (2009). Domestic Space Narrative Research and Its Reflection. Jiangxi Social Sciences, (1), 42-47. Retrieved https://kns.cnki.net/KCMS/detail/detail.aspx ?dbcode $=$ CJFQ\&dbname $=$ CJFD2009\& filename $=J X S H 200901$ 007\&v=MjQ0MjJYWVpyRzRIdGpNcm85Rlk0UjhlWDFMdXhZUzdEaDFUM3FUcldNMUZyQ1VSN3F mWmVadUZ5SG5WNy9OTHo=

Delillo, D. (2010). Point Omega. New York: Picador.

Friedman, N. (1955). Point of View in Fiction: The Development of a Critical Concept. PMLA, 70(5), 1160-1184. https://doi.org/10.2307/459894

Genette, G. (1990). Narrative Discourse. New York, NY: Cornell University Press.

Long, D. (2014).Spatial Narratology. Guangdong, Guangdong: SDX Joint Publishing Company.

Mitchell, W. J. T. (Spring, 1980). Spatial Form in Literature: Toward a General Theory. Critical Inquiry, 6(3), 539-567. https://doi.org/10.1086/448064

Ning, M., \& Zhang, W. (2013). A Brief Survey on Domestic Spacial Narratology Studies. Journal of Changchun Normal University, 32(9), 124-127. http://kns.cnki.net/KXReader/Detail?TIMESTAMP=637161799289288750\&DBCODE=CJFQ\&TABLENa $\mathrm{me}=\mathrm{CJFD} 2013 \&$ FileName $=$ CCSS201309040\&RESULT $=1 \&$ SIGN $=\mathrm{x} 045 \mathrm{dRZAncHaB20juHRE0YBAEfQ}$ $\% 3 \mathrm{~d}$

Ronen, R. (1986). Space in Fiction. Poetics Today, 7(3), 421-438. https://doi.org/10.2307/1772504

Shen, D. (2004). Narrative Studies and Stylistics of Novels. Beijing, Beijing: Peking University Press.

Sun, W. (2018). Review and Comment on the Domestic Spatial Narrative Research (Master's thesis). Hubei Normal University, Hubei, China. Retrieved from https://kns.cnki.net/KCMS/detail/detail.aspx?dbcode=CMFD\&dbname=CMFD201802\&filename $=1018119$ 602.nh\&v=MDYwMTBmTXJaRWJQSVI4ZVgxTHV4WVM3RGgxVDNxVHJXTTFGckNVUjdxZlplWn VGeUhnVWJ6SIZGMjZGcks1Rjk=

Zoran, G. (1984). Towards a Theory of Space in Narrative. Poetics Today, 5(2), 309-335. https://doi.org/10.2307/1771935

\section{Copyrights}

Copyright for this article is retained by the author(s), with first publication rights granted to the journal.

This is an open-access article distributed under the terms and conditions of the Creative Commons Attribution license (http://creativecommons.org/licenses/by/4.0/). 